\title{
Sapiehas estate document from the end of the 17 th century as a source of the family's economic and political history
}

https://doi.org/10.1515/openps-2018-0014

received December 16, 2018; accepted December 23, 2018.

\begin{abstract}
Property documents and more precisely, the inventories of earthly goods can be very helpful in explaining complicated political affairs. Also the nobles' names, which are mentioned in registers, may show us the influence and the composition of the nobility, from which the lider's property were leased. Residents of manors, which belonged to the Sapieha Family, actually were forced to gain some contact and be dependent on the Family, even if it was a part of economic relations, which could easily be transformed into a personal one. However, the manor reliances undoubtedly opened up opportunities for both sides, which juxtaposed the benefits and losses with possible closer cooperation. Despite property ties, by analyzing the mentioned document we can find out (among other knowledge) the information about subordination and independence. Moreover it is possible to take the notice of the moodiness of the political scene or of the global political tendencies of residents what was the scope of interests for researcher of economists and goods.
\end{abstract}

Keywords: Sapiehas; Grand Duchy of Lithuania; catalogue.

Property documents, or more precisely inventories of landed and leased royalties, can be used by historians for multidimensional studies not only related to the economic history. Of course, we could find information there about

1 The article was created as a result of scientific research carried out as part of the project PRELUDIUM 12 entitled "Attitudes of the elite of the Grand Duchy of Lithuania towards the election of Wladysław IV Waza and Michal Korybut Wisniowiecki” (project no. UMO2016/23/N/HS3/00679) financed by the National Science Center in Krakow.

*Corresponding author: Aleksandra Ziober, Department of Economic History, Demography and Statistic, Institute of History, University of Wroclaw, Poland, E-mail: aleksandra.ziober@uwr.edu.pl the number of chimneys ${ }^{2}$ (in Polish: dymów) or leased lands and certainly these data are very important for people specializing in research in the history of taxes and broadly understood economics. On the other hand, land property inventories may serve to answer complicated political questions, and the names of the noblemen listed may show us the influence and composition of the magnate faction, from whom the leader leased property. Thanks to this, the analyzed manuscript material becomes a source of comprehensive application for the historian. Therefore, in this article, I would like to focus primarily on the analysis of socio-political connections of people appearing in the property document referred in the title of the article, and thus demonstrate the legitimacy of using this type of material for extensive research.

The analyzed manuscript containing a list of the Sapieha family property, which at the end of the 17th century obtained a dominant position in the Grand Duchy of Lithuania and is kept in the collection of the Science Library of Polish Academy of Learning and the Polish Academy of Sciences in Krakow under the manuscript number $5787^{3}$. Unfortunately, the manuscript has not been preserved in its entirety, therefore the date of its preparation and title cannot be found in it. Some cards have been damaged or destroyed, making it difficult or impossible to read the tenants' names recorded there. According to the archivist working on the inventory of the document, it is from the first years of the 18th century and contains information about the chimneys in the estates and properties of the Great Pantler of Lithuania, Jerzy Stanislaw Sapieha. The document was prepared for Timofiej Iwanowicz Czyryk, a lieutenant colonel in the tsarist army. It is most likely that it comes from the turn of the 17th and 18th centuries as some of its elements indicate. Among others, the document mentioned a few

2 Unit of tax calculations in the former Polish-Lithuanian Commonwealth; a country cottage or farm.

3 Biblioteka Naukowa Polskiej Akademii Umiejętności i Polskiej Akademii Nauk w Krakowie, ms. 5787, 1, 4-13, 15, $22-23$. 
people like the Great Marshal of Lithuanian Jan Karol Dolski, Gedeon (Stanislaw?) Hladowicki, Stanislaw Massalski and the Cupbearer ("cześnik") of Smolensk Jerzy Bury - all of whom died between 1691 and 1698, and on the other hand, officials who obtained their offices only in 1700 (e.g. Andrzej Hieronim Przeclawski, Deputy District Judge ("podsędek") of Slonim ${ }^{4}$. In this connection, the author inclines to the thesis that the document dates from the beginning of the 18th century, which is also evidenced by the fact that the document was drawn up on the orders of the lieutenant colonel of the tsarist army, who probably stayed in the Commonwealth in the first years of the Great Northern Wars.

Research on the manuscript material would not be complete without, at least in general analysis, the political situation of the Sapieha family during the reign of Jan III Sobieski, whose activity led to mentioned noblemen's hegemony at the end of the seventeenth century. After the election, the King, wanting to overcome the influence of the Pac family in the Grand Duchy of Lithuania, decided to oppose the sons of Pawel Jan Sapieha (who died in 1665) - Benedykt Pawel, Kazimierz Jan, Franciszek Stefan and Leon Bazyli. Within a few years after the election of Jan III to be the king, they received several of the most important offices in Lithuania: the Lithuanian Grand Treasurer, the Lithuanian Grand Hetman and the Voivode of Vilnius, and, what is also important, the support of the monarch. Gaining more and more influence in Lithuania, they quickly used their abilities and start to be in opposition to the King, and at the end of the 1680s, they became indisputable hegemonies in the Grand Duchy. The first visible activities of the opposition to the Sapiehas appeared in the first half of the 1690s. The Bishop of Vilnius Konstanty Kazimierz Brzostowski supported by the monarch, cursed Kazimierz Sapieha in relation to the allegedly unlawful distribution of military banners in the priest property. This initiated an avalanche of political events that eventually ended in a civil war and a battle between the republics and the followers of Sapiehas near Olkieniki on November 18, 1700. After losing the battle, the Lithuanian hegemons were forced to leave Grand Duchy ${ }^{5}$.

4 Biblioteka Naukowa Polskiej Akademii Umiejętności i Polskiej Akademii Nauk w Krakowie, ms. 5787, 13; Российский государственный архив древних актов, Москва, f. 389 (Metryka Litewska), No. 146, 279; A. Rachuba (Ed.), Urzędnicy Wielkiego Księstwa Litewskiego. Spisy, Vol. 1, Województwo wileńskie, Wydawnictwo DiG Warszawa, 2004, 233 (in Polish); A. Rachuba (ed.), Urzędnicy Wielkiego Księstwa Litewskiego. Spisy, Vol. 4, Ziemia smoleńska i województwo smoleńskie XIV-XVIII wiek, Wydawnictwo DiG, Warszawa, 2003, 66 (in Polish).

5 A. Rachuba, Sprawa obsady urzędów litewskich po Sapiehach w początkach XVIII wieku, In: K. Wajda and others (Eds.), Między
One of the most important determinants of the political and social position of the noblemen's family was the landed possessions, both those inherited from the ancestors and those obtained from royal grants. It seems that especially the former were of great political importance, and as Henryk Lulewicz said, they created somehow a bond "in the chain of causes that gave the elite at the same time an intermediary function between the king and the corporations of the county nobility represented by land council and a dominant position over the nobility". So, the magnates with extensive latifundium had the greatest importance, and through their proper distribution, they could expand their political influence among the gentry, who were economically dependent on them ${ }^{6}$.

This is perfectly illustrated by the financial situation of the most influential sons of Pawel Jan Sapieha - Kazimierz Jan and Benedykt Pawel. It should be remembered that their hegemony was based mainly on strong economic foundations. In the 1690s, Kazimierz Jan was the richest nobleman of the Grand Duchy, whose hereditary goods amounted to almost 18 thousand chimneys. From 1695, he also managed to possess very lucrative Neuburg goods (over 14,000 chimneys ). His brother, Benedykt Pawel, had a slightly smaller property, presumably about 9,000 chimneys, although for tax purposes he declared less than half of them. Adding all the chimneys belonging to the family (mother, sons, nephews from the Czerejska line), the Sapiehas owned about $10 \%$ of them in Lithuania, and with Neuburg goods up to $15 \%$, which gives a sum of around 30,000 chimneys. For example, it could be stated

wielką polityką a szlacheckim partykularzem. Studia z dziejów nowożytnej Polski i Europy ku czci profesora Jacka Staszewskiego, Wydawnictwo Uniwersytetu Mikołaja Kopernika, Toruń, 1993, 253-254 (in Polish); K. Piwarski, Opozycja litewska pod koniec XVII wieku, In: Pamiętnik V Powszechnego Zjazdu Historyków Polskich w Warszawie 18 listopada do 4 grudnia 1930 r. i referaty, Polskie Towarzystwo Historyczne, Lwów, 1930, 262-263 (in Polish); L. Powidaj, Wojna domowa Sapiehów z szlachtą litewską w ostatnich latach XVII i na początku XVIII wieku. Szkic historyczny, Przegląd Polski, Vol. 7, No. 4, 1872, 69 (in Polish); K. Nizio, Wojna domowa szlachty z Sapiehami na pióra, Pamiętniki Biblioteki Kórnickiej, No. 22, 1988, 125-126 (in Polish); M. Sawicki, Konflikt biskupa wileńskiego Konstantego Kazimierza Brzostowskiego z Kazimierzem Janem Sapiehą w latach 1693-1696, In: S. Górzyński, M. Nagielski (Eds.), Studia z dziejów Wielkiego Księstwa Litewskiego XVI-XVIII w., Wydawnictwo DiG, Warszawa, 2014, 383-401 (in Polish).

6 M. Sawicki, Dom sapieżyński 1666-1685. Droga do hegemonii w Wielkim Księstwie Litewskim, Wydawnictwo Uniwersytetu Opolskiego, Opole, 2016, 196 (in Polish); H. Lulewicz, Elita polityczno-społeczna Wielkiego Księstwa Litewskiego w połowie XVII wieku, PhD thesis, University of Warsaw, Warsaw, Poland, 1984, 282-283 (in Polish). 
that the Radziwills, who were in opposition to them, owned approx. 12,000 chimneys in total at that time. Contrary to the Pac's policy, Benedykt Pawel and Kazimierz Jan were mainly pledging or renting family goods ${ }^{7}$.

Below in the article we present persons or families who had the greatest influence on Poland's national and local political scenes. We will analyze their political attitudes towards the Sapieha family and their attitude to the conflict, which has reached a dramatic climax in the Battle near Olkieniki. The other noblemen listed in the inventory are included in the tables as annexes at the end of the article.

Analyzing the presented document, it is worth paying attention to the members of the Polubinscy family, who were mentioned many times in it and owned goods in various estates belonging to the Sapieha family. Aleksander Hilary should certainly be the most important representative of the Polubinski family. He began his political career under the reign of Jan Kazimierz Vasa. Then, he received the office of the Grand Lithuanian Marshal during the reign of Michal Korybut Wisniowiecki in 1669. Aleksander Hilary died in 1679 and, among other things, he left his daughter Izabella Helena. She is mentioned in the presented material and was to own property in the Lukonicka parish ${ }^{8}$. Interestingly, Izabella Helena married the Lithuanian Pantler Jerzy Stanislaw Sapieha, the son of the Grand Lithuanian Hetman, Kazimierz Jan, who was also mentioned in the inventory as the tenant of goods in the Dereczynska parish'

Another member from the Polubinscy family who was mentioned several times in the list, was Leon Kazimierz, voivode of Nowogrodek and Bailiff of Twer ("Ciwun Twerski"). He was supposed to own property in the Dereczyńska parish and in the royal lands leased by the Sapieha family ${ }^{10}$. He was the son of Dimitri Samuel Polubinski, voivode of Nowogrodek and Konstancja from Stadnicki family, the daughter of Wiktoryn the Castellan of

7 A. Rachuba, Hegemonia Sapiehów na Litwie jako przejaw skrajnej dominacji magnaterii w życiu kraju, In: J. Urwanowicz, E. DubasUrwanowicz, P. Guzowski (Eds.), Władza i prestiż. Magnateria Rzeczypospolitej w XVI-XVII wieku, Wydawnictwo Uniwersytetu w Białymstoku, Białystok, 2003, 223, 225 (in Polish); M. Sawicki, Dom sapieżyński 1666-1685. Droga do hegemonii w Wielkim Księstwie Litewskim, Wydawnictwo Uniwersytetu Opolskiego, Opole, 2016, 199 (in Polish).

8 Biblioteka Naukowa Polskiej Akademii Umiejętności i Polskiej Akademii Nauk w Krakowie, ms. 5787, 6.

9 A. Rachuba, Sapieha Jerzy Stanisław, Polski Słownik Biograficzny, Vol. 35, No. 1, Warszawa-Kraków 1994, 21 (in Polish).

10 Biblioteka Naukowa Polskiej Akademii Umiejętności i Polskiej Akademii Nauk w Krakowie, ms. 5787, 5v, 8.
Przemysl $^{11}$. In 1698, Leon Kazimierz Polubinski appeared at a mass mobilization of noblemen (in Polish: pospolite ruszenie) gathering in Samogitia (between Lawna and Puzewicze), where on August 14 he signed the act of the state of the Grand Duchy of Lithuania. In 1699 he was appointed as the deputy from the Duchy of Samogitia to a pacificator parliament against Sapieha's hegemony. Perhaps he participated in the Battle near Olkieniki, however, the resolution of the state of the Grand Duchy of Lithuania from November 2, does not mention him as one of the signatories of the document. Probably he was in the Samogitian banner commanded by Hrehory Oginski, which were not included in the above document ${ }^{12}$.

The inventory also lists the next son of Dymitr Samuel, Michal Aleksander Polubinski, District Judge of Slonim. Probably, he owned goods in the Dereczynska parish ${ }^{13}$. Interestingly, three of his sons were also mentioned twice: Hieronim, Kazimierz and Franciszek. All three were supposed to possess property in the royal lands of the Sapiehas and in the Kosonska parish ${ }^{14}$.

The collection also lists several other members of the Polubinscy family. One of them was recorded under the name "Remian" and as a son of voivode of Nowogrodek, so it certainly had to be another son of Dymitr Samuel, Remigian Stanislaw, Chamberlain of Slonim, whose career was associated primarily with the army. Among other things, he was the Standard-bearer of the banner (in Polish: chorazy choragwi) of the Hussar belonging to the Grand Lithuanian Marshal Aleksander Hilary Polubinski. He owned property in the royal lands leased by the Sapiehas and in the Dereczynska parish ${ }^{15}$.

The inventory also mentioned twice Ludwik Polubinski, but without the office he held. We could assume that it was Ludwik Aleksander who was a Cupbearer of Slonim from 1690. He owned property (as did

11 A. Rachuba, Połubiński Dymitr Samuel, Polski Słownik Biograficzny, Vol. 27, No. 3, 366 (in Polish).

12 M. Nagielski, Połubiński Leon Kazimierz, Polski Słownik Biograficzny, Vol. 27, No. 3, 369 (in Polish).

13 Biblioteka Naukowa Polskiej Akademii Umiejętności i Polskiej Akademii Nauk w Krakowie, ms. 5787, 6; A. Rachuba, Połubiński Dymitr Samuel, Polski Słownik Biograficzny, Vol. 27, No. 3, 366 (in Polish).

14 Biblioteka Naukowa Polskiej Akademii Umiejętności i Polskiej Akademii Nauk w Krakowie, ms. 5787, 4v, 8-8v.

15 Biblioteka Naukowa Polskiej Akademii Umiejętności i Polskiej Akademii Nauk w Krakowie, ms. 5787, 5v and 8; A. Rachuba, Połubiński Dymitr Samuel, Polski Słownik Biograficzny, Vol. 27, No. 3, 366 (in Polish); A. A. Majewski, Aleksander Hilary Połubiński (16271679). Marszałek wielki litewski. Działalność polityczno-wojskowa, Wydawnictwo Neriton, Warszawa, 2017, 432 (in Polish). 
the above-mentioned Polubinscy) in the royal lands and in the Dereczyńska parish ${ }^{16}$.

Lease of many goods in Sapieha's latifundia may testify to the fact that they attempted to make the Polubinscy family depend on them, which is also confirmed by the aforementioned marriage of the son of Kazimierz Jan, Franciszek Stefan with Izabela Helena. Based on the analyzed inventory, it seems very likely that after the death of its most influential member, Aleksander Hilary, the Sapieha family wanted to use the opportunity to persuade the members of his family and faction to join their side. However, it seems that their efforts did not end well.

Jan Wladyslaw Brzostowski, son of Cyprian Brzostowski and Rachela Rajecka, was also mentioned in the analyzed inventory. He was the brother of Konstanty Bishop of Vilnius, who cast the aforementioned curse on Kazimierz Jan. He began his career under the rule of Michal Korybut Wisniowiecki and in 1669 he became a Starost of Subocz. He obtained the highest office in his career in 1681 when he became a Lithuanian Referendary. He belonged to the opposition movement to the Sapieha family, and in 1698 he was one of the noble plenipotentiaries in negotiations with them. He had goods in the royal lands leased by the Sapiehas, but it does not seem that he cooperated with them politically ${ }^{17}$.

Michal Karol Haraburda, the Marshal of Slonim, son of Mikolaj Jerzy, was also mentioned in the inventory. He owned property in the Lukonicka parish in Ostrewia, Bajki, Klimowicze and Rewtowicze. Between the Haraburda and Aleksander Hilary Polubinski from 1667, there was a serious conflict, which began with the rivalry for the Lithuanian Lord High Steward. Probably the Grand Lithuanian Marshal even invaded the armed goods of Haraburda, then the "wojski" 18 of Slonim. As a result, the political scene in Lithuania was polarized, the Pac family supported Polubinski, and Haraburda - the RadziwillSapieha party. In 1671, Benedykt Pawel Sapieha openly wrote to Haraburda that he supported his case against

16 Biblioteka Naukowa Polskiej Akademii Umiejętności i Polskiej Akademii Nauk w Krakowie, ms. 5787, 5v and 8; A. A. Majewski, Aleksander Hilary Połubiński (1627-1679). Marszałek wielki litewski. Działalność polityczno-wojskowa, Wydawnictwo Neriton, Warszawa, 2017, 432 (in Polish).

17 Biblioteka Naukowa Polskiej Akademii Umiejętności i Polskiej Akademii Nauk w Krakowie, ms. 5787, 10v; K. Piwarski, Brzostowski Jan Władysław, Polski Słownik Biograficzny, Vol. 3, No. 1, Kraków, 1937, 49 (in Polish).

18 Polish lower office. The assistant of the starost during the mas mobilization (in Polish: pospolite ruszenie); he looked after left families and estates. the approaching land councils. After the death of Michal Kazimierz Radziwill in 1680, the Sapieha family began taking over his party, probably also including Haraburda, who could be described as their follower. It seems that he also maintained contacts with the Radziwill family. He probably abandoned service for Sapiehas at the beginning of the 1690s. In 1698, he was part of the opposition to the Sapieha family and brought to the Republican camp the banner of the Slonim gentry. Together with Wladyslaw Wollowicz, he represented the Slonim County during the negotiation with Sapiehas. A year later, he was elected a deputy for the pacification parliament. During the Battle near Olkieniki he commanded the Slonim banner ${ }^{19}$.

One of the most important officials who was mentioned in the inventory was Jan Karol Dolski, the Grand Lithuanian Marshal. He owned property in the royal lands leased by Sapieha ${ }^{20}$. In the 1670s, he became associated with the royal court, in which he received the office of the Lithuanian Royal Cupbearer (in Polish: "podczaszy") in 1676, and after the death of Jan Karol Mlocki, he became a Starost of Pińsk. In the 1680s, the Sapiehas tried to drag him to their faculties by the timely and comprehensive settlement of financial obligations towards his branch, which amounted to 12,240 polish zloty for two-quarters of service. Possession of property in Sapieha-administered goods could have meaning in a political configuration, and it seems that Lithuanian hegemons intended to persuade Dolski to join their side. They could apply the tenant's persuasion to the possessors of certain goods, or simply to influence the number of various obligations that were to be paid to the Sapieha treasury. In the case of Dolski, all Sapieha's actions ended in failure, and the aforementioned entered into a sharp conflict with Kazimierz Jan, which nearly ended with a sabres duel. In 1689, there was an agreement between Dolski and the Sapiehas, and the antagonisms between the two diminished in strength. After receiving in 1691 the office of the Grand Lithuanian Marshall, upon the death of Stanislaw Radziwill, Dolski moved away from political life, occupied with private matters. In the end, the plans

19 Biblioteka Naukowa Polskiej Akademii Umiejętności i Polskiej Akademii Nauk w Krakowie, ms. 5787, 6; M. Sawicki, Dom sapieżyński 1666-1685. Droga do hegemonii w Wielkim Księstwie Litewskim, Wydawnictwo Uniwersytetu Opolskiego, Opole, 2016, 66-69, 151-152 (in Polish); T. Wasilewski, Haraburda Michał Karol, Polski Słownik Biograficzny, Vol. 9, No. 3, Wrocław-Warszawa-Kraków 1960-1961, 290 (in Polish).

20 Biblioteka Naukowa Polskiej Akademii Umiejętności i Polskiej Akademii Nauk w Krakowie, ms. 5787, 8. 
of Benedykt Pawel and Kazimierz Jan ended in fiasco, and Dolski remained faithful to the court ${ }^{21}$.

One of the more recognizable magnates, who was connected economically with the Sapiehas, is starost, and later the voivode of Minsk, Krzysztof Zawisza and his wife Teresa from the Tyszkiewicz family. Both of them owned goods in the Lukonicka parish ${ }^{22}$. Through this marriage, Zawisza became involved with the Sapieha family, because the mother of Teresa Zawisza (nee Tyszkiewicz) was Teodora Aleksandra, daughter of Grand Lithuanian Hetman Pawel Jan Sapieha ${ }^{23}$. The starost of Minsk was a deputy for parliaments several times in the 1680s and 1690s. He also took part in the parliament in 1693 during which he was to cooperate "well with the Sapiehas". After the death of Jan III, he was appointed to the law court during the interregnum and held the post of a deputy for the convocation parliament. The good relations between Zawisza and the Sapiehas deteriorated, however, after an incident which took place during the period of the confederation in Lithuania. It was reported to the Voivode of Minsk that the soldiers led by Paleja intend to get to Hetman Sapieha, and therefore they were detained by Zawisza, which was to Kazimierz Jan's dissatisfaction and led to a breakdown of cooperation. Despite this misunderstanding, however, the district head of Minsk tried to maintain good relations with the Sapiehas. During the interregnum in 1696, the hegemons sought to strengthen their cooperation with Zawisza again. However, the position that the starost found in the court of the new king did not suit them. In 1698 he was elected the Marshal of a land council in Minsk during which he effectively blocked the nobility's demands regarding to the invasion of the Sapieha's estate. He informed the Sapieha family about the moods among the nobility and that "he was not against them, and that he did not want to ruin them, even if he had reasons to let the nobles go free". Over the next few months, Zawisza tried to ease the nervousness of the nobility, who were already very opposed to Sapieha's domination. In the end, both families reconciled, which led to a decrease in popularity of the starost of Minsk among the nobility. When he appeared in the camp at

21 K. Piwarski, Dolski Jan Karol, Polski Słownik Biograficzny, Vol. 5, No. 3, 288-289 (in Polish); M. Sawicki, Dom sapieżyński 1666-1685. Droga do hegemonii w Wielkim Księstwie Litewskim, Wydawnictwo Uniwersytetu Opolskiego, Opole, 2016, 120, 223, 239 (in Polish).

22 Biblioteka Naukowa Polskiej Akademii Umiejętności i Polskiej Akademii Nauk w Krakowie, ms. 5787, 6.

23 A. Rachuba, Sapieha Paweł Jan, Polski Słownik Biograficzny, Vol. 35, No. 1, 147 (in Polish); K. Zawisza, Pamiętnik Krzysztofa Zawszy wojewody mińskiego 1666-1721, J. Bartoszewicz (Ed.), Drukarnia Gazety Polskiej, Warszawa, 1862, 8 (in Polish).
Kamionka, where a mass mobilization (in Polish: pospolite ruszenie) against the hegemons was gathered "he found a stir, that was threatening, and anger". Still faithful to the Sapiehas he appeased the mood of the nobility during the "gromniczny" council in Minsk in 1700 "and seeing that more and more was leading to a civil war" he decided to make a pilgrimage to Rome and therefore did not take part in the Battle near Olkieniki. Therefore, he did not have to talk to any of the parties in the conflict ${ }^{24}$.

It seems that Krzysztof Zawisza and his wife were one of the few representatives of the nobility who cooperated with the Sapiehas until the end of their hegemony. Through the marriage with Pawel Jan's granddaughter, as well as economic dependence from Kazimierz Jan and Benedykt Pawel, the Starost of Minsk was in a way condemned to cooperate with the family. Faithful to his ideals of protecting the nobility's freedom and family ties with the Sapiehas, he probably decided to withdraw from the conflict in Lithuania and, not wanting to stand up to either side and consequently lose his authority among the nobility, he went on a journey to Rome. However, we have information that in 1702 Krzysztof Zawisza was recruited by the Sapieha family and formed an armed Cossack banner against the Republicans. He also participated in further fights with the Sapiehas' opposition ${ }^{25}$.

The document also mentions the Chamberlain of Polock Benedykt Ignacy Przysiecki, who probably possessed property on the royal lands leased by Sapieha ${ }^{26}$. He was related to Celestine Przysiecki and both came from a well-off family in the Voivodeship of Polock. Kazimierz Jan Sapieha give the latter properties called Skakuny in 1681. The Przysiecki family was probably a clientele of Aleksander Hilary Polubinski, which is evidenced by the fact that he gave Benedykt, the chamberlain of Polock, goods named Kozmiany in the voivodeship of Polock, what was confirmed in 1670. In addition, Benedykt Przysiecki married Konstancja from Chaleccy, the niece of the Grand Lithuanian Marshal, which in a way bound him to Polubinski. This may, therefore, confirm the aforementioned thesis that after the death of Polubinski the Sapiehas tried to take over his clientele by offering them lands and making them economically dependent

24 K. Zawisza, Pamiętnik Krzysztofa Zawszy wojewody mińskiego 1666-1721, J. Bartoszewicz (Ed.), Drukarnia Gazety Polskiej, Warszawa, 1862, 9-17 (in Polish).

25 T. Ciesielski, Wojsko litewskie w latach 1698-1709, In: B. Dybaś (Ed.), Wojny północne w XVI-XVIII wieku. W czterechsetlecie bitwy pod Kircholmem, Wydawnictwo Naukowe Uniwersytetu Mikołaja Kopernika, Torun, 2007, 174 (in Polish).

26 Biblioteka Naukowa Polskiej Akademii Umiejętności i Polskiej Akademii Nauk w Krakowie, ms. 5787, 8. 
on them ${ }^{27}$. It seems that the Przysiecki family, through property donations and leases held in Sapieha-controlled areas, was their political clientele.

The three members of the Wollowicz family were also mentioned in the analyzed document: Wladyslaw, the Carver ("krajczy") of Samogitia; Kazimierz, the Pantler ("stolnik") of Upita; and Jerzy, the Chamberlain of Slonim. All of them possessed property in the royal lands leased by the Sapiehas, and Kazimierz also owned goods in the Dereczynska parish ${ }^{28}$. In their case, it is difficult to find accurate information about their political affiliation, but it is highly probable that they were clients of the Grand Lithuanian Marshal Alexander Hilary Polubinski. We only have more information about the Pantler ("stolnik") of Upita Kazimierz Aleksander, whom Andrzej A. Majewski counted as one of the servants of the aforementioned Lithuanian Marshal. In his youth, he was to be a companion in his Cossack banner. Wollowicz was even mentioned by Polubinski in his will, in which he offered him 2,000 polish zloty for his loyalty ${ }^{29}$. The mention of the Wollowicz family, especially of Kazimierz Aleksander, in the inventory, confirms that the Sapiehas tried to intercept the clientele of Aleksander Hilary Polubinski with a positive result and through the property contacts become more tied to the faction of Benedykt Pawel and Kazimierz Jan.

The inventory also mentioned Dominik Aleksander Tyszkiewicz, Pantler ("stolnik") of Slonim, who was supposed to possess property in the Kosonska parish ${ }^{30}$. He was associated with the faction of Sapiehas since the $1680 \mathrm{~s}^{31}$. His brother Mikolaj Castellan of Smolensk, son of Piotr, was also mentioned in the inventory. He possessed property in the royal lands leased by the Sapiehas ${ }^{32}$. It can be assumed that, as a brother, he was in their faction.

27 M. Sawicki, Dom sapieżyński 1666-1685. Droga do hegemonii w Wielkim Księstwie Litewskim, Wydawnictwo Uniwersytetu Opolskiego, Opole, 2016, 200-201 (in Polish); A. A. Majewski, Aleksander Hilary Połubiński (1627-1679). Marszałek wielki litewski. Działalność polityczno-wojskowa, Wydawnictwo Neriton, Warszawa, 2017, 19, 301, 433 (in Polish).

28 Biblioteka Naukowa Polskiej Akademii Umiejętności i Polskiej Akademii Nauk w Krakowie, ms. 5787, 5 i 8.

29 A. A. Majewski, Aleksander Hilary Połubiński (1627-1679). Marszałek wielki litewski. Działalność polityczno-wojskowa, Wydawnictwo Neriton, Warszawa, 2017, $439-440$ (in Polish).

30 Biblioteka Naukowa Polskiej Akademii Umiejętności i Polskiej Akademii Nauk w Krakowie, ms. 5787, 4v.

31 M. Sawicki, Dom sapieżyński 1666-1685. Droga do hegemonii w Wielkim Księstwie Litewskim, Wydawnictwo Uniwersytetu Opolskiego, Opole, 2016, 151 (in Polish).

32 Biblioteka Naukowa Polskiej Akademii Umiejętności i Polskiej Akademii Nauk w Krakowie, ms. 5787, 8.
The Sapiehas' political strength and influence was also impacted by the masses of the petty gentry who, through participation in the sessions of a local council and the election of suitable deputies for parliament, could have been instrumental in decisions taken at the highest state level. This group includes Kazimierz Puslowski, Steward ("podstoli") of Rzeczyca, who owned the property in the Olszewska parish and the royal lands leased by Sapiehas. The nobleman were certainly their supporters, because during the session of the regional council of Starodub in Vilnius in 1695, he supported the memorial published by them, and took part in the local councils, which were to devise ways of calming the tensions in the Polish-Lithuanian Commonwealth ${ }^{33}$. The analyzed inventory also mentions, but only by name, Owsiany and Brodowski. It is possible that it refers to Adam Owsiany, who was a Standard-bearer ("chorąży") of Wolkowysk and to Stanislaw Brodowski. Both were mentioned in 1695 and both also supported the Sapiehas' memorial during the local nobility council of the county of Wolkowysk, which was managed by Owsiany. Nobles gathered at this regional council also attacked Konstanty Brzostowski for casting a curse on Kazimierz Jan Sapieha ${ }^{34}$.

In the inventory, we also find confirmation that the Sapiehas intercepted the Radziwill clientele after the death of Michal Kazimierz. In addition to the aforementioned Michal Karol Haraburda, we could mention the land judge of Slonim, Stefan Brzuchanski, who as Slonim's Deputy District Judge ("podsędek"), supported Boguslaw Radziwill's activities at the local council at the end of the $1660 \mathrm{~s}^{35}$.

In the analyzed inventory of goods of the Sapiehas, we could also find many more surnames of nobles holding various types of land offices, in particular, in the county of Slonim, including, among others: Chamberlain ("podkomorzowie"), Starosts, Deputy District Judges ("podsędkowie") and District Clerk ("pisarze ziemscy"). Residents of the royal economy leased by the Sapiehas, had to maintain contact woth them and have some form of dependence on this family. For example, some types of

33 Ibidem, 5, 8; A. Rachuba, Litwa wobec projektu zwołania sejmu konnego w 1695 r. i walki Sapiehów z biskupem Brzostowskim, Zapiski Historyczne, Vol. 51, No. 1, 1986, $73-74$ (in Polish).

34 Biblioteka Naukowa Polskiej Akademii Umiejętności i Polskiej Akademii Nauk w Krakowie, ms. 5787, 5v and 8; A. Rachuba, Litwa wobec projektu zwołania sejmu konnego w 1695 r. i walki Sapiehów z biskupem Brzostowskim, Zapiski Historyczne, Vol. 51, No. 1, 1986, 74 (in Polish).

35 K. Bobiatyński, W walce o hegemonię. Rywalizacja polityczna w Wielkim Księstwie Litewskim w latach 1667-1674, Wydawnictwo Neriton, Warszawa, 2016, 62. 
economic connections could have easily be transformed into client and personal relations. Not every person among the large number of tenants mentioned in the document was willing to cooperate, which does not mean that attempts to take over individual people's loyalties were not made, although with different results. It should also be remembered that inconsistent "foreign policy" (the corruption of relations with Vienna, impermanent alliance with France, or finally the transition to the Swedes) of Sapiehas led to the depletion of their party and loss of trust in the society. Undoubtedly, however, property dependencies opened up some possibilities for both parties, who combined benefits and losses from possible closer cooperation.

Table 1: List of noblemen living in the estates of Jerzy Stanislaw Sapieha - division into parishes36.

\begin{tabular}{|c|c|}
\hline Leased goods: no data available & \\
\hline Name, surname of tenant & Office, held dignity \\
\hline Boguslaw Zienkowicz & \\
\hline Zofia Kosakowska & \\
\hline Janowa (?) Sawicka & \\
\hline Wierzejska & \\
\hline Molczadzka parish & \\
\hline Name, surname of tenant & Office, held dignity \\
\hline Stefan Wojnilowicz & \\
\hline Wollowicz ${ }^{37}$ & \\
\hline Janowa Michalowska & \\
\hline Stefan Michalowski & \\
\hline Wladyslaw Okulicz & \\
\hline Szabranski & \\
\hline Szyszka & \\
\hline Stefan Brzuchanski & District Judge of Slonim \\
\hline Wojciech Buczynski & Tresurer of Rzeczyca \\
\hline Jerzy Wollowicz & Chamberlein of Slonim \\
\hline Bagiński & \\
\hline Kazimierz Wieckiewicz & \\
\hline Stanislaw Kirojwa (?) & \\
\hline Stefan Miechenski (?) & \\
\hline Jan Ladzinski & \\
\hline Zawadzka & \\
\hline Laniewski & \\
\hline Jacynicz & \\
\hline Bankonscy family (?) & \\
\hline Aleksander Czeczot & \\
\hline
\end{tabular}

36 Unreadable words have been marked with a sign: (?). As far as possible, the author tried to decipher and identify the persons listed in the inventory.

37 Perhaps the above mentioned Stefan Wołłowicz. 
Continued Table 1: List of noblemen living in the estates of Jerzy Stanislaw Sapieha - division into parishes.

\begin{tabular}{ll}
\hline Molczadzka parish & \\
\hline Name, surname of tenant & Office, held dignity \\
\hline Ludwik Gieysztor & \\
Piotr Kurocki & \\
Michal Borkowski & Son of Chamberlain \\
Chryzostom Karp & \\
Kuroczyski & \\
\hline
\end{tabular}

Kosonska parish

Name, surname of tenant

Office, held dignity

Franciszek Suchodolski

Albrycht Mierzejewski

“wojski” of Lida

Dominik Aleksander Tyszkiewicz

Pantler ("stolnik") of Slonim

Stanislaw Tuteński

Żabka

Komorowicz

Hieronim Polubinski

Son of District Judge of Slonim

Kazimierz Polubinski

Ibid.

Franciszek Polubinski

Ibid.

Dernalowicz

Hieronim Suchodolski

Stanislaw Massalski

Master of Hunt ("łowczy”) of Oszmiana

Olszewska parish

Name, surname of tenant Office, held dignity

Andrzej Hieornim Przeclawski

Deputy District Judge (“podsędek”) of Slonim

Andrzej Olszewski

Kazimierz Olszewski

Pustowska

Adamowa Paplinska

Franciszek Kuszel

Berguszewski

Wladyslaw Olszewski

Kazimierz Puslowski

Steward (“ podstoli”) of Rzeczyca

Eustachy Suchodolski

Sterpińska (?) 
Continued Table 1: List of noblemen living in the estates of Jerzy Stanislaw Sapieha - division into parishes.

\begin{tabular}{|c|c|}
\hline Rozanska parish & \\
\hline Name, surname of tenant & Office, held dignity \\
\hline Aleksander Bykowski & \\
\hline Franciszek Mieleszko & \\
\hline Piotr Mieleszko & \\
\hline Zalecilo & \\
\hline Jerzy Giedroyć & \\
\hline Karnicki & \\
\hline Ślizień & \\
\hline Świechoński (?) & \\
\hline Brodowski & \\
\hline Kolyszko (?) & \\
\hline Stefan Mizgier & \\
\hline Mikolaj Mizgier & \\
\hline Aleksander Mrokowski & \\
\hline Krzysztof Mizgier & \\
\hline Stefan Hutycz & \\
\hline Marcinkiewicz from Mizgierowie & \\
\hline Dereczyńska parish & \\
\hline Name, surname of tenant & Office, held dignity \\
\hline Jerzy Stanislaw Sapieha & Great Pantler (“stolnik”) of Lithuania \\
\hline Bykowska & wife of Starost of Slonim \\
\hline Michal Polubinski & District Judge of Slonim \\
\hline Kazimierz Aleksander Wizgin Wollowicz & Pantler (“stolnik") of Upita \\
\hline Leon Polubinski & Bailiff of Twer (“ciwun twerski”) \\
\hline Remian Polubinski & \\
\hline Ludwik Polubinski & \\
\hline Wincenty Bulhak & \\
\hline Franciszek Choinski & \\
\hline Haraburda ${ }^{38}$ & \\
\hline Kos (?) & \\
\hline Lukonicka parish & \\
\hline Name, surname of tenant & Office, held dignity \\
\hline Izabella Polubinski from Sapieha family & wife of Pantler ("stolnik") of Lithuania \\
\hline Michal Karol Haraburda & Marshall of Slonim \\
\hline Bujno[?] & \\
\hline
\end{tabular}

38 Perhaps Michał Karol Haraburda, Marshall of Slonim. 
Continued Table 1: List of noblemen living in the estates of Jerzy Stanislaw Sapieha - division into parishes.

\begin{tabular}{|c|c|}
\hline \multicolumn{2}{|l|}{ Lukonicka parish } \\
\hline Name, surname of tenant & Office, held dignity \\
\hline \multicolumn{2}{|l|}{ Pienicki } \\
\hline \multicolumn{2}{|l|}{ Makowiecki } \\
\hline Jan Konstanty Ciechanowicz & Master of the Hunt (“łowczy”) of Smolensk \\
\hline Lesonski [?] & Master of the Hunt ("łowczy") of Slonim \\
\hline \multicolumn{2}{|l|}{ Makowiecki } \\
\hline \multicolumn{2}{|l|}{ Jakub Sznetla } \\
\hline \multicolumn{2}{|l|}{ Hordziewski } \\
\hline \multicolumn{2}{|l|}{ Pawel Wojnilowicz } \\
\hline \multicolumn{2}{|l|}{ Kaciuciewicz } \\
\hline \multicolumn{2}{|l|}{ Sasuliczowie } \\
\hline \multicolumn{2}{|l|}{ Haraburda ${ }^{39}$} \\
\hline \multicolumn{2}{|l|}{ Michal Siehen } \\
\hline \multicolumn{2}{|l|}{ Jan Plawski } \\
\hline \multicolumn{2}{|l|}{ Florian Kosikonski (?) } \\
\hline \multicolumn{2}{|l|}{ Czarniszewski } \\
\hline \multicolumn{2}{|l|}{ Kotowicz } \\
\hline \multicolumn{2}{|l|}{ Jerzy Zukowski } \\
\hline \multicolumn{2}{|l|}{ Czernik } \\
\hline \multicolumn{2}{|l|}{ Jarasewicz } \\
\hline Jakimowicz & “horodniczy” of Slonim \\
\hline \multicolumn{2}{|c|}{ Rohotenska and dworzecka prishes. Parts in county of Slonim } \\
\hline Name, surname of tenant & Office, held dignity \\
\hline Krzysztof Zawisza & Starost of Minsk and Czeczew \\
\hline \multicolumn{2}{|l|}{ Michal Czyżewski } \\
\hline \multicolumn{2}{|l|}{ Rafal Czechowicz } \\
\hline \multicolumn{2}{|l|}{ Piasecki } \\
\hline \multicolumn{2}{|l|}{ Konstanty Wlochowicz } \\
\hline Teresa Zawisza from Tyszkiewicz family & wife of Starost of Breslaw \\
\hline \multicolumn{2}{|l|}{ Totokowski (?) } \\
\hline \multicolumn{2}{|l|}{ Rychalski } \\
\hline \multicolumn{2}{|l|}{ Szulc } \\
\hline \multicolumn{2}{|l|}{ Jacenty Zelislawski } \\
\hline \multicolumn{2}{|l|}{ Krzywkowski (?) } \\
\hline Hieronim Strzyzewski & \\
\hline
\end{tabular}

39 Perhaps Michał Karol Haraburda. 
continued Table 1: List of noblemen living in the estates of Jerzy Stanislaw Sapieha - division into parishes.

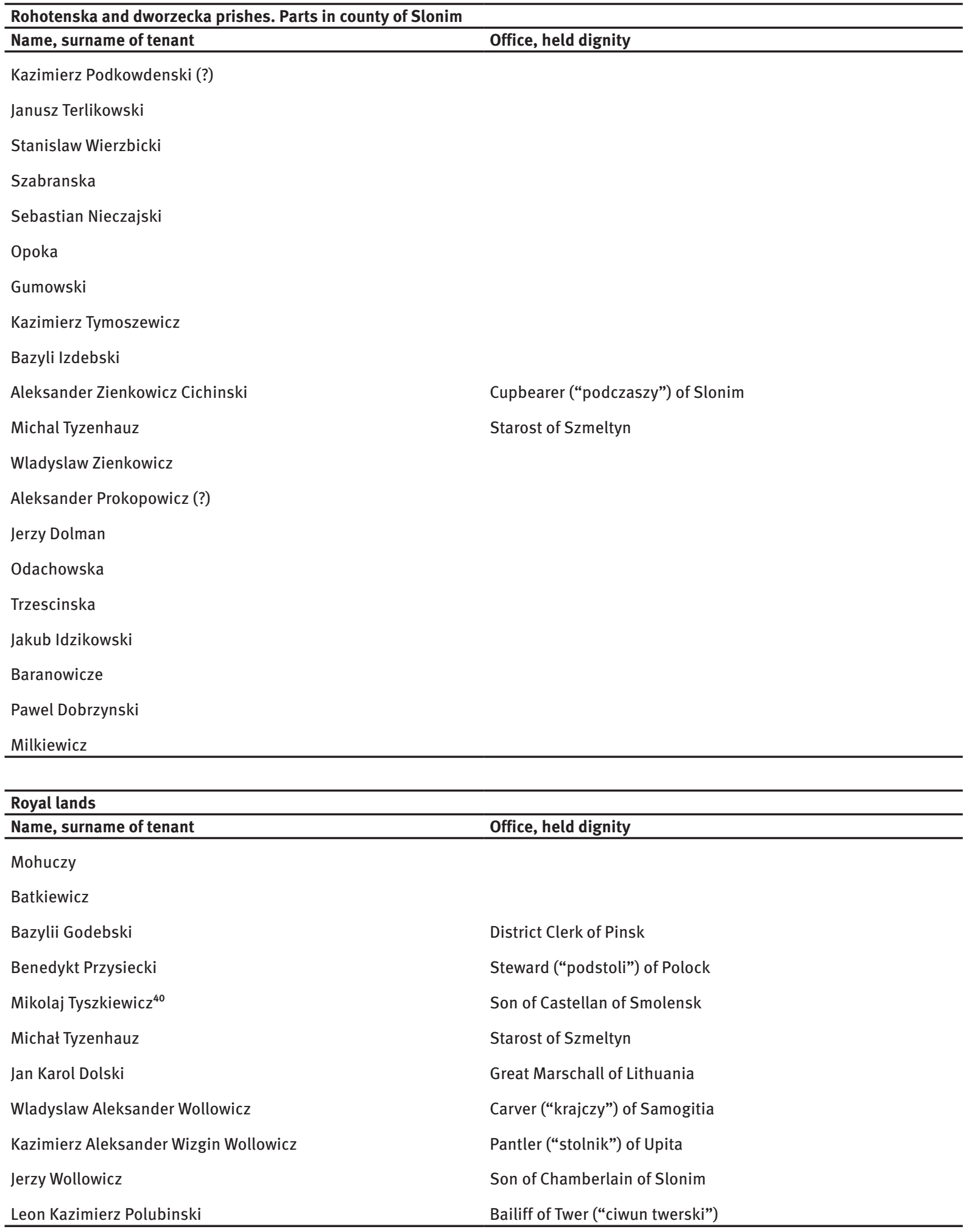

40 Son of Piotr Tyszkiewicz, Castellan of Smolensk, Marshal of Slonim who died in 1663.; Urzędnicy Wielkiego Księstwa Litewskiego. Spisy, Vol. 4, Ziemia smoleńska i województwo smoleńskie XIV-XVIII wiek, Wydawnictwo DiG, Warszawa, 2003, 90 (in Polish). 
Continued Table 1: List of noblemen living in the estates of Jerzy Stanislaw Sapieha - division into parishes.

\begin{tabular}{|c|c|}
\hline \multicolumn{2}{|l|}{ Royal lands } \\
\hline Name, surname of tenant & Office, held dignity \\
\hline Remian Polubinski & Son of voivode of Nowogrodek \\
\hline \multicolumn{2}{|l|}{ Ludwik Polubinski } \\
\hline Kazimierz Przeslawski & Starost of Bialsk \\
\hline Stefan Przeslawski & Pantler ("stolnik") of Brzesc Litewski \\
\hline Gedeon (Stanislaw?) Hladowicki & Steward (“podstoli”) of Grodno \\
\hline Chryzostom Karp ${ }^{41}$ & Son of Chamberlain of Bielsk \\
\hline Albrycht Boguslaw Mirzejewski (Mierzejewski?) & "wojski” of Lida \\
\hline Michal Posowski (?) & Master of Hunt ("łowczy") of Slonim \\
\hline Aleksander Uniechowski & Son of Standard-bearer ("chorąży") of Minsk \\
\hline \multicolumn{2}{|l|}{ Pokorszenska (?) } \\
\hline \multicolumn{2}{|l|}{ Owsiany ${ }^{42}$} \\
\hline Aleksander Bykowski & Cupbearer (“cześnik”) of Slonim \\
\hline Hieronim Polubinski & Son of District Judge of Slonim \\
\hline Kazimierz Polubinski & Ibid. \\
\hline Franciszek Polubinski & Ibid. \\
\hline Kazimierz Puslowski & Steward ("podstoli”) of Rzeczyca \\
\hline Bykowska & Wife of Vice-starost of Slonim \\
\hline \multicolumn{2}{|l|}{ Aleksander Chlusewicz } \\
\hline Jan Konstanty Ciechnowicz & Master of Hunt ("łowczy") of Smolensk \\
\hline \multicolumn{2}{|l|}{ Makowiecki } \\
\hline Krzysztof Wojnilowicz & Royal cupbearer (“podczaszy”) of Mozyrz \\
\hline \multicolumn{2}{|l|}{ Hieronim Suchodolski } \\
\hline Franciszek Suchodolski & Tresurer of Slonim \\
\hline Stanislaw Massalski & Master of Hunt ("łowczy") of Oszmiana \\
\hline \multicolumn{2}{|l|}{ Michal Karnicki } \\
\hline \multicolumn{2}{|l|}{ Jan Zabka } \\
\hline Mateusz Jesman & Son of Standard-bearer ("chorąży") of Slonim \\
\hline \multicolumn{2}{|l|}{ Pacyna } \\
\hline Franciszek Jordan & Royal Cupbearer (“podczaszy”) of Braslaw \\
\hline Franciszek Antoni Choinski & "wojski” of Krasnystaw \\
\hline Jan Jurjewicz & Sword-bearer (“miecznik”) of Polock \\
\hline
\end{tabular}

41 He was probably the son of Józef Karp, Chamberlain of Bielsko; Elektorów poczet, którzy niegdyś głosowali na elektorów Jana Kazimierza roku 1648, Jana III. roku 1674, Augusta II. roku 1697, i Stanisława Augusta roku 1764, najjaśniejszych Królów Polskich, Wielkich Książąt Litewskich, itd., composed and published by Oswald Zaprzaniec from Siemuszowa Pietruska, Lwów, 1845, 140.

42 Perhaps it was about Adam Owsian, Standard-bearer of Wołkowysk; A. Rachuba, Litwa wobec projektu zwołania sejmu konnego w 1695 r. i walki Sapiehów z biskupem Brzostowskim, Zapiski Historyczne, Vol. 51, No. 1, 1986, 74 (in Polish). 
Continued Table 1: List of noblemen living in the estates of Jerzy Stanislaw Sapieha - division into parishes.

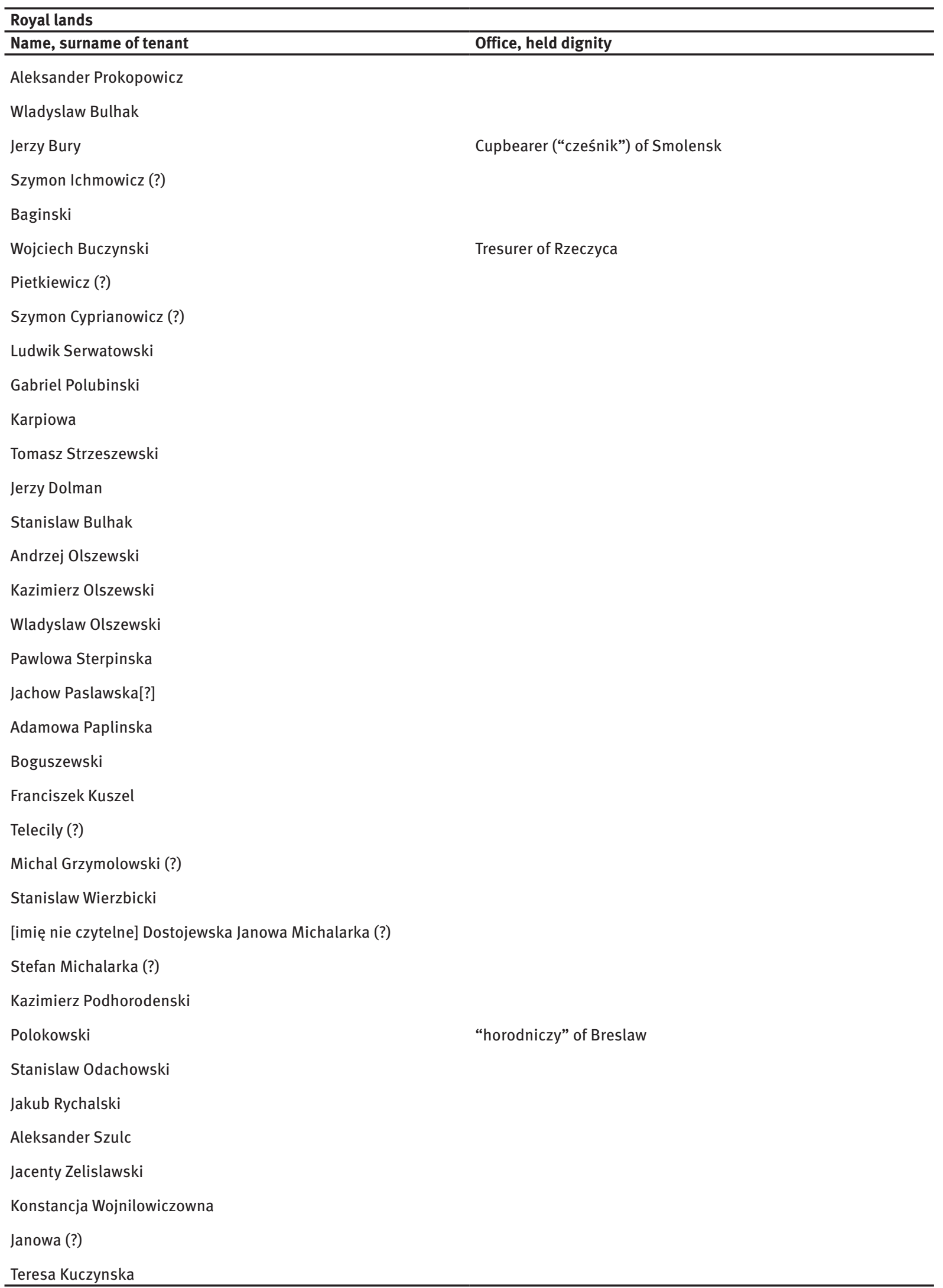


Continued Table 1: List of noblemen living in the estates of Jerzy Stanislaw Sapieha - division into parishes.

\begin{tabular}{|c|c|}
\hline Royal lands & \\
\hline Name, surname of tenant & Office, held dignity \\
\hline Sebastian Nieczajski & \\
\hline Mikolajowa Zawadzka & \\
\hline Jan Gumowski & \\
\hline Kazimierz Mickiewicz & \\
\hline Daniel Ladzinski & \\
\hline Opoka & \\
\hline Andrzej Zaburk (?) & \\
\hline Teodor Pupik (Tupik?) & \\
\hline Aleksander Kuncewicz & \\
\hline Womperski & \\
\hline Stankiewicz & \\
\hline Czerkaski & \\
\hline Stanislaw Wolk & \\
\hline Andrzej Piskun (?) & \\
\hline Stefan Mizgier & \\
\hline Mikolaj Mizgier & \\
\hline Konstanty Wlochowicz & \\
\hline Michal Gejzewski & \\
\hline Jan Wladyslaw Brzostowski & Great Referendary of Lithuania \\
\hline Malkiewiczowie & \\
\hline Wawrzyniec Szebranski & \\
\hline Aleksander Czeczot & \\
\hline Piotr Kuwczycki (?) & \\
\hline Lukasz Gieysztor & \\
\hline Brzuchanski & City Judge ("sędzia grodzki") of Slonim \\
\hline Jacynicz & \\
\hline Zabka & \\
\hline Kirczycz & \\
\hline Susewiczowie & \\
\hline Skorulski & \\
\hline Dominik Bulhak & \\
\hline Okulicz & \\
\hline Bulhak & \\
\hline Suchodolski & \\
\hline Baranowicz & \\
\hline Mohuczy & \\
\hline
\end{tabular}


Table 1: List of noblemen living in the estates of Jerzy Stanislaw Sapieha - division into parishes.

\begin{tabular}{l}
\hline Royal lands \\
\hline Name, surname of tenant \\
\hline Jezierski family \\
Gujski \\
Bobola \\
Pacyna \\
Komorowicz
\end{tabular}

Undoubtedly, the analyzed economic document is an invaluable source not only for examining financial, tax or other related issues. Studying it also influences the recognition of the correlation between the owner and the tenant on many levels. We can find information about subordination and independence, in spite of property connections, and in the longer term about the changing moods on the political scene, or global political tendencies of residents, which is a valuable source for economics and goods researchers ${ }^{43}$.

\section{Bibliography}

\section{Manuscripts}

Biblioteka Naukowa Polskiej Akademii Umiejętności i Polskiej Akademii Nauk w Krakowie: ms. 5787.

Российский государственный архив древних актов, Москва: f. 389 (Metryka Litewska), No. 146.

\section{Printed sources}

[1] Elektorów poczet, którzy niegdyś głosowali na elektorów Jana Kazimierza roku 1648, Jana III. roku 1674, Augusta II. roku 1697, i Stanisława Augusta roku 1764, najjaśniejszych Królów Polskich, Wielkich Książąt Litewskich, i.t.d., composed and published by Oswald Zaprzaniec from Siemuszowa Pietruska, Lwów 1845.

[2] Zawisza K., Pamiętnik Krzysztofa Zawszy wojewody mińskiego 1666-1721, J. Bartoszewicz (Ed.), Drukarnia Gazety Polskiej, Warszawa, 1862, 8 (in polish).

43 G. Silesoriūnas, Walka stronnictw w przededniu i podczas wojny domowej na Litwie XVII/XVIII wieku, In: J. Urwanowicz, E. Dubas-Urwanowicz, P. Guzowski, Władza i prestiż. Magnateria Rzeczypospolitej w XVI-XVIII wieku, Wydawnictwo Uniwersytetu w Białymstoku, Białystok, 2003, 231-232.

\section{Literature}

[1] Bobiatyński K., W walce o hegemonię. Rywalizacja polityczna w Wielkim Księstwie Litewskim w latach 1667-1674, Wydawnictwo Neriton, Warszawa, 2016 (in polish).

[2] Ciesielski T., Wojsko litewskie w latach 1698-1709, In: B. Dybaś (Ed.), Wojny północne w XVI-XVIII wieku. W czterechsetlecie bitwy pod Kircholmem, Wydawnictwo Naukowe Uniwersytetu Mikołaja Kopernika, Toruń, 2007 (in polish).

[3] Lulewicz H., Elita polityczno-społeczna Wielkiego Księstwa Litewskiego w połowie XVII wieku, PhD thesis, University of Warsaw, Warsaw, Poland, 1984 (in polish).

[4] Majewski A. A., Aleksander Hilary Połubiński (1627-1679). Marszałek wielki litewski. Działalność polityczno-wojskowa, Wydawnictwo Neriton, Warszawa, 2017 (in polish).

[5] Nagielski M., Połubiński Leon Kazimierz, Polski Słownik Biograficzny, Vol. 27, No. 3 (in polish).

[6] Nizio K., Wojna domowa szlachty z Sapiehami na pióra, Pamiętniki Biblioteki Kórnickiej, No. 22, 1988 (in polish).

[7] Piwarski K., Brzostowski Jan Władystaw, Polski Stownik Biograficzny, Vol. 3, No. 1, Kraków, 1937 (in polish).

[8] Piwarski K., Dolski Jan Karol, Polski Stownik Biograficzny, Vol. 5, No. 3 (in polish).

[9] Piwarski K., Opozycja litewska pod koniec XVII wieku, In: Pamiętnik V Powszechnego Zjazdu Historyków Polskich w Warszawie 18 listopada do 4 grudnia 1930 r. i referaty, Polskie Towarzystwo Historyczne, Lwów, 1930 (in polish).

[10] Powidaj L., Wojna domowa Sapiehów z szlachtą litewską w ostatnich latach XVII i na początku XVIII wieku. Szkic historyczny, Przegląd Polski, Vol. 7, No. 4, 1872 (in polish).

[11] Rachuba A. (Ed.), Urzędnicy Wielkiego Księstwa Litewskiego. Spisy, Vol. 1, Województwo wileńskie, Wydawnictwo DiG Warszawa, 2004 (in polish).

[12] Rachuba A. (Ed.), Urzędnicy Wielkiego Księstwa Litewskiego. Spisy, Vol. 4, Ziemia smoleńska i województwo smoleńskie XIVXVIII wiek, Wydawnictwo DiG, Warszawa, 2003 (in polish).

[13] Rachuba A., Hegemonia Sapiehów na Litwie jako przejaw skrajnej dominacji magnaterii w życiu kraju, In: J. Urwanowicz, E. Dubas-Urwanowicz, P. Guzowski (Eds.), Władza i prestiż. Magnateria Rzeczypospolitej w XVI-XVII wieku, Wydawnictwo Uniwersytetu w Białymstoku, Białystok, 2003 (in polish).

[14] Rachuba A., Litwa wobec projektu zwołania sejmu konnego w 1695 r. i walki Sapiehów z biskupem Brzostowskim, Zapiski Historyczne, Vol. 51, No. 1, 1986, $73-74$ (in polish) 
[15] Rachuba A., Połubiński Dymitr Samuel, Polski Stownik Biograficzny, Vol. 27, No. 3 (in polish).

[16] Rachuba A., Połubiński Dymitr Samuel, Polski Stownik Biograficzny, Vol. 27, No. 3, (in polish).

[17] Rachuba A., Sapieha Jerzy Stanisław, Polski Stownik Biograficzny, Vol. 35, No. 1, Warszawa-Kraków 1994, (in polish).

[18] Rachuba A., Sapieha Paweł Jan, Polski Słownik Biograficzny, Vol. 35, No. 1, (in polish).

[19] Rachuba A., Sprawa obsady urzędów litewskich po Sapiehach w początkach XVIII wieku, In: K. Wajda and others (Eds.), Między wielką polityką a szlacheckim partykularzem. Studia z dziejów nowożytnej Polski i Europy ku czci profesora Jacka Staszewskiego, Wydawnictwo Uniwersytetu Mikołaja Kopernika, Toruń, 1993 (in polish).

[20] Sawicki M., Dom sapieżyński 1666-1685. Droga do hegemonii w Wielkim Księstwie Litewskim, Wydawnictwo Uniwersytetu Opolskiego, Opole, 2016 (in polish).

[21] Sawicki M., Konflikt biskupa wileńskiego Konstantego Kazimierza Brzostowskiego z Kazimierzem Janem Sapiehą w latach 1693-1696, In: S. Górzyński, M. Nagielski (Eds.), Studia z dziejów Wielkiego Księstwa Litewskiego XVI-XVIII w., Wydawnictwo DiG, Warszawa, 2014 (in polish).

[22] Silesoriūnas G., Walka stronnictw w przededniu i podczas wojny domowej na Litwie XVII/XVIII wieku, In: J. Urwanowicz, E. Dubas-Urwanowicz, P. Guzowski, Władza i prestiż. Magnateria Rzeczypospolitej w XVI-XVIII wieku, Wydawnictwo Uniwersytetu w Białymstoku, Białystok, 2003 (in polish).

[23] Wasilewski T., Haraburda Michał Karol, Polski Stownik Biograficzny, Vol. 9, No. 3, Wrocław-Warszawa-Kraków 19601961 (in polish). 